\title{
Is Executive Compensation a Substitute Governance Mechanism to Debt Financing and Leasing?
}

\author{
Marizah Minhat \\ School of Accounting, Financial Services and Law \\ Edinburgh Napier University \\ Craiglockhart Campus \\ Edinburgh EH14 1DJ \\ Scotland \\ United Kingdom \\ m.minhat@napier.ac.uk
}

\author{
Nazam Dzolkarnaini* \\ Salford Business School \\ University of Salford \\ Salford M5 4WT \\ United Kingdom \\ n.dzolkarnaini@salford.ac.uk
}

(Applied Economics, forthcoming)

JEL classification: G32, G34, J33, M52

Keywords: Executive compensation, CEO pay, CEO incentives, Capital structure, Debt, Leasing, Corporate governance

* Corresponding author 


\title{
Is Executive Compensation a Substitute Governance Mechanism to Debt Financing and Leasing?
}

\begin{abstract}
This study examines whether and how CEO equity incentives relate to financing choices (i.e., debt and leases). Using manually collected CEO compensation and lease data for a sample of large UK firms, we found evidence of a negative relationship between CEO equity incentives and firm leverage. We also found that CEO equity incentives and leases are negatively related. The results are consistent with the theory introduced in this study on the substitutability of executive compensation and firm's debt/lease financing. Our findings represent fresh empirical evidence and renewed interpretation regarding the relationship between executive equity-based incentives and firm's financing choices. The substitutability theory we introduced here suggests that firms with greater use of debt and/or leases will implement less equity-based compensation in mitigating the agency cost of equity.
\end{abstract}

JEL classification: G32, G34, J33, M52

Keywords: Executive compensation, CEO pay, CEO incentives, Capital structure, Debt, Leasing, Corporate governance 


\section{Introduction}

The agency cost of equity arises from the misalignment of interests between the managers of the firm and the shareholders of the firm (Jensen and Meckling, 1976; John and John, 1993). In the agency theory framework, managers are subject to selfserving behaviours such as using corporate resources to pursue private benefits instead of investing in good investment projects. To mitigate the agency cost of equity, many corporate finance studies (e.g., Jensen, 1986; Jensen and Meckling, 1976) have recognised the benefit of using debt in disciplining managers to be efficient in utilising corporate resources. Whereas, studies on executive compensation have identified the use of equity-based compensation to induce managers to invest in good investment projects instead of using such resources for their private benefits (e.g., Brick, Palmon and Wald, 2006; Core, Holthausen and Larcker, 1999; Kuang and Qin, 2009).

Considering the two strands of studies, we can view that debt financing and equitybased compensation as corporate governance substitutes to mitigate the agency cost of equity. If this two corporate governance mechanisms are substitutes, we can expect that firm will balance the use of debt financing with the use of equity-based compensation because each of them is expected to produce identical effect on the agency cost of equity. Apart from debt, lease is another fixed-claimed financing which can be viewed as another disciplinary mechanism to ensure managers use corporate resources more efficiently. Treating leases as playing a similar role to debt is consistent with the lease-debt substitutability theory (Beattie, Goodacre and Thomson, 2000). Our study contributes by testing the substitutability of debt/leases and equitybased compensation, which has not been documented in prior literature. 
We use manually collected CEO compensation and lease data for a balanced panel of 700 firm-year observations over a five-year period. It involves 140 firms in the United Kingdom for the period from 1999 to 2003. We find evidence of a negative relationship between CEO equity incentives and firm leverage. We also find that CEO equity incentives and leases are negatively related. The results are consistent with the theory introduced in this study on the substitutability of equity-based compensation and firm's debt/lease financing. This theory suggests that firms with greater use of debt and/or leases to discipline managers will implement less equity-based compensation in mitigating the agency cost of equity.

The remainder of this paper is structured as follows. The second section presents the development of the substitutability theory and hypotheses. The description of the data and the definition of variables are presented in the third section. The empirical results of the study are presented in the fourth section. Finally, the last section presents the conclusions.

\section{The Development of Substitutability Theory and Hypotheses}

\subsection{Debt as a Disciplinary Mechanism for Interest Alignment}

The presence of agency costs which arise from the separation of ownership and control is widely acknowledged in the corporate finance literature. The agency theory predicts that managers of the firm will have a tendency to use corporate resources for private benefits instead of investing them in good investment projects. The detrimental effect of managerial self-serving behaviour has been documented in many studies. For example, Yermack (2006) finds that the average shareholder returns of firms that have disclosed their CEO's personal use of corporate jets, underperformed market 
benchmarks by more than $4 \%$ annually. Around the date of the initial disclosure, the firms' stock prices dropped by an average of $1.1 \%$.

The agency theory also acknowledges the benefit of debt in mitigating the conflict of interests between shareholders and managers (Jensen and Meckling, 1976). Further, Jensen's (1986) controlling hypothesis suggests that the use of debt will reduce the agency cost of free cash flows by reducing the cash flow available for spending at the discretion of managers hence reduce the opportunity for self-serving managers to abuse such corporate resources. By issuing debt, managers are bonded to their promises to pay out future cash flows in a way that cannot be accomplished by dividend as in the case of equity financing. Failure to fulfil such promises in the form of interest payments and principal repayment will lead to bankruptcy hence managers will lose their jobs. Therefore, the presence of debt will discipline the managers to use corporate resources more appropriately and efficiently.

\subsection{Executive Compensation as an Incentive Mechanism for Interest Alignment}

The agency theory also predicts that the agency costs of equity caused by managerial self-serving behaviour can be mitigated by linking managerial compensation with shareholder wealth through equity-based pay (Jensen and Meckling, 1976; Jensen and Murphy, 1990). Consistent with this theory, empirical studies on executive compensation have shown that manager-shareholder interest alignment (i.e., positive pay-for-performance sensitivity) is strengthened when a greater proportion of equitybased schemes are used in executive pay packages (Hall and Liebman, 1998; Murphy, 1999). 
The equity-based pay refer to the granting of stock and stock options to the CEOs (Hall and Liebman, 1998). Managers awarded with stock options will be more motivated to invest in positive net present value projects, instead of using corporate resources for private benefits, with a view to increase the firm's stock price. The managers will then be able to profitably exercise the stock options by buying the firm's shares at the exercise price, which is lower than the prevailing market price in the case of rising stock price. The same incentive effect can be expected in the case of stock grants because stock grants can be viewed as stock options with zero exercise price. Since the values of both stock options and stock grants are positively related to stock price, managers will be encouraged to alleviate inefficient use of resources that could be detrimental to firm performance.

\subsection{The Substitutability of Debt Financing and Leasing}

In the traditional leasing theory, lease financing is recognised as a common mechanism for reducing the agency costs of debt (e.g., Mehran, Taggart and Yermack, 1999; Krishnan and Moyer, 1994; Smith and Warner, 1979; Stulz and Johnson, 1985). Some studies argued that firm risk is lower when assets are financed using leases rather than debt. For instance, a firm that purchases an asset must engage in a potentially costly disposal when the asset becomes obsolete and must simultaneously pay off the debt financing that was previously obtained to purchase the asset. If the firm leases the asset instead, the firm will not bear the obsolescence risk as well as the asset-specific risks as the risks are shifted to the lessors. By implication, leasing can reduce a firm's risk hence protecting its debt value. Therefore, debtholders will have a greater incentive to induce firms to take on more leases as in the case of debt-leasing complementary (e.g., Adams and Hardwick, 1998). 
However, although leasing can reduce a firm's risk hence protecting its debt value, both leases and debt entail a commitment to a set of fixed payments. Because of this feature, the lease-debt substitutability theory recognises lease as a substitute of debt (e.g., Beattie, Goodacre and Thomson, 2000; Mehran, Taggart and Yermack, 1999). By examining 410 firms that do not engage in leasing and 98 firms with finance leases on their balance sheets over the 1984-1986 period, Krishnan and Moyer (1994) document a significant negative relationship between lease ratios and debt ratios. Similar findings are documented by Adedeji and Stapleton (1996), who examine a sample of UK firms for the period from 1990 to 1992. The findings of these studies are consistent with the lease-debt substitutability theory.

\subsection{The Substitutability of Executive Compensation and Debt/Leases for Interest}

\section{Alignment}

The substitutability of executive compensation and debt/leases as corporate governance mechanisms in mitigating the agency cost of equity has not been documented in prior compensation and capital structure studies [e.g., (Ertugrul and Hegde (2008); John, Mehran and Qian (2010); Ortiz-Molina (2007); Robicheaux, Fu and Ligon (2008)]. Zhang (2009) explores the substitutability of debt and equity-based compensation without incorporating the substitutability effect of leases. The substitutability of leases was also not explored in John and John (1993). Building upon the agency theory, we argue that debt/leasing contracts and equity-based compensation can be viewed as disciplinary and incentives mechanisms, respectively, for managers to use corporate resources more efficiently hence improve firm performance. These governance mechanisms can substitute each other. This implies 
that firm can resort to equity-based compensation if debt and/or leases are not available to reduce the agency cost of equity. The substitutability theory introduced here leads to the following hypotheses:

Hypothesis 1. There is a negative relationship between CEO equity incentives and debt.

Hypothesis 2. There is a negative relationship between CEO equity incentives and leases.

\section{Data}

To test the hypotheses regarding the relationship between CEO equity incentives and debt, and CEO equity incentives and leases, we selected a sample from FTSE350 firms. The exclusion of financial firms is a common practice and we adopt this approach to maintain comparability with other studies (e.g., Ertugrul and Hegde, 2008; Ortiz-Molina, 2007). Following Ortiz-Molina (2007), firms without enough historical data (due to reasons such as takeover/listed and data non-availability) were excluded from the sample. This process has produced a balanced panel data of 700 firm-year observations over a five-year period (i.e., 140 firms for the period from 1999 to 2003). Panel A of Table 1 summarises the sample selection process.

Insert Table 1 about here

Panel B of Table 1 shows the industry distribution of sample firms. Firms are classified into a number of industries according to the Primary Standard Industrial Classification Codes that are obtained from the Financial Analysis Made Easy (FAME) database. Overall, the sample firms represent several industrial sectors. The largest number of firms (59 firms) belongs to the manufacturing sector, followed by the wholesale and 
retail trade sector (23 firms) and the construction sector (14 firms). Both CEO pay and operating lease data are manually collected from the annual reports of the firms.

\subsection{CEO Equity Incentives}

CEO equity incentives is the dependent variable in our regressions. Following Conyon, Core and Guay (2011), we measure equity incentives (i.e., pay-forperformance sensitivity) as (share price) $\times($ the number of shares held $)+($ share price $)$ $\times($ option delta $) \times($ the number of options held $)$. This incentive measure is a scaled version (i.e., multiplied by 100) of a commonly used incentive measure: the dollar change in a CEO's wealth from a $1 \%$ stock price increase (Conyon, Core and Guay, 2011).

\subsection{Leverage and Leasing}

Following many studies (e.g., Beattie, Goodacre and Thomson, 2000; Graham, Lemmon and Schallheim, 1998; Ortiz-Molina, 2007), we measure leverage by the book value of long-term debt (net of finance leases) divided by the adjusted book value of a firm. The adjusted book value of a firm equals the book value of total assets minus the book value of equity plus the market value of equity plus the present value of operating lease assets. Note that this value is adjusted to include the effect of operating leases, which are not reported on the balance sheet. Although the finance lease figures are available from the annual reports of the firms, the figures for operating lease assets and liability are estimated using the constructive capitalisation method (Beattie, Edwards and Goodacre, 1998). To ensure robustness, we define market leverage as the book value of long-term debt (net of finance leases) divided by the adjusted market value of a firm. Prior studies have commonly separated leasing measures into finance 
and operating lease measures (e.g., Robicheaux, Fu and Ligon, 2008). Similar to debt, the long-term portion of leases are used and measured against a firm's adjusted book value (and the market value for robustness checks).

\subsection{Other Variables}

The following variables are included in the regression model: firm size, growth opportunities, board composition, CEO ownership and tenure. Firm size is the natural logarithm of sales for a year. Sales are a common measure of firm size (e.g., Brick, Palmon and Wald, 2006). Growth opportunities are measured by the adjusted marketto-book ratio (Adam and Goyal, 2008; Bevan and Danbolt, 2002; Ortiz-Molina, 2007). Other corporate governance variables are measured by the number of executive directors divided by the number of non-executive directors, the percentage of a firm's common stock owned by CEO (Brick, Palmon and Wald, 2006), and the number of years that the CEO has held the position of CEO at a firm. The definitions of the variables are presented in the appendix.

\section{Empirical Tests and Results}

\subsection{Descriptive Statistics}

We find that $79 \%$ of the firm-years award stock options and/or stock grants to their CEOs during 1999-2003. The mean (median) value of CEO equity incentives is $£ 9.5$ million ( $£ 1.3$ million). This figure is comparable to the mean (median) of $£ 13.5$ million (£2.3 million) reported in Conyon, Core and Guay (2011) for the year 2003.

Insert Table 2 about here 
The mean values for the finance and operating lease ratios, based on the adjusted book value, are $1 \%$ and $8 \%$, respectively. These figures are broadly similar with those that have been reported in the US (Graham, Lemmon and Schallheim, 1998). The mean value for book leverage is $19 \%$. These figures are lower than those that have been reported in the US (24\%) (Ortiz-Molina, 2007). As reported in previous studies, the indebtedness level of UK firms is relatively lower than that of US firms (e.g., de Jong, Kabir and Nguyen, 2008).

Sales, which constitute a measure of firm size, have a mean (median) value of $£ 3.6$ billion ( $£ 1.3$ billion). As a measure of growth opportunities, the market-to-book ratio has a mean (median) value of 2.06 (1.43). The average CEO has been employed as a CEO of his or her firm for six years. Similar to the work of Kuang and Qin (2009), we find that the average board has 10 members with equal proportions of executive and non-executive directors. The correlation analysis show that the correlation coefficients for the key variables that are used in our analysis are small.

Figure 1 presents the scatter diagrams for the key explanatory variables, which are debt, finance lease and operating lease. It can be observed that debt (DRM) and finance lease (FLRM) are positively correlated. This implies that firms that are strongly debt financed also make use of finance lease and vice versa. In an unreported correlation, the correlation coefficient between DRM and FLRM is 0.4125 ( $p$-value $<0.01)$. This observation is consistent with debt-leasing complementary theory that we have discussed in Section 2.3 earlier. 
The scatter diagram indicate no correlation between debt (DRM) and operating lease (OLRM). The correlation coefficient is -0.0607 ( $p$-value $<0.01$ ), which is not statistically significant. This implies that neither debt-leasing complementary theory nor debt-leasing substitutability theory can be applied. We also observe no correlation between finance lease (FLRM) and operating lease (OLRM).

\subsection{Regression Results}

The relationship between leverage and CEO equity incentives is first examined without controlling for the effect of leasing to ensure a better comparison with previous studies. Tobit, OLS and fixed effects estimates are used, and the results are presented in Table 3. Following Ertugrul and Hegde (2008), we use a Tobit regression because of the presence of substantial cases of zero-valued CEO equity incentives. The fixed effects estimates are preferred over the random effects estimates based on the results of Hausman test. ${ }^{1}$

Insert Table 3 about here

The dependent variable is CEO equity incentives (INCENT). Consistent with our first hypothesis, Columns 1 and 2 of Table 3 show that book leverage (DRB) is negatively related to CEO equity incentives. The relationship is even stronger when market leverage (DRM) is used, as reported in Columns 3, 4 and 5. The negative relationship between firm leverage and CEO equity incentives is consistent with previous findings (e.g., Ortiz-Molina, 2007). These results are also consistent with our first hypothesis that suggest the substitutability of equity incentives and debt. 
We then examine the relationship between finance leases and CEO equity incentives without controlling for the effect of leverage. As reported in Columns 1, 2 and 3 of Table 4, the regression specifications produce consistent results that suggest market measure of finance leases (FLRM) is negatively related to CEO equity incentives. The study of Robicheaux, Fu and Ligon (2008) presents similar results. The results for operating leases are reported in Columns 4, 5 and 6. As shown in Column 6, operating lease, as measured by its market value (i.e., OLRM), is also negatively related to CEO equity incentives. Overall, there is strong evidence to suggest the substitutability of equity incentives and leases. The negative coefficients on OLRM shown in Columns 4 and 5 are also consistent with this hypothesis, although the coefficients are not statistically significant.

Insert Table 4 about here

For the coefficient on FLRM, all three specifications (Columns 1 to 3) yield significant estimate, though the FE estimate $(-10.7323 * * *)$ is smaller in magnitude than the estimates of tobit $\left(-17.2745^{* * *}\right)$ and OLS $\left(-16.9312^{* * *}\right)$. Columns 4 and 5 report that the coefficients on OLRM as statistically insignificant whereas the FE estimate in column 6 produces a significantly large coefficient $(-7.5342 * *)$. The results reported in Columns 1, 2, 4 and 5 of Table 4 have to be interpreted more cautiously because the estimates were produced by tobit and OLS, which disregard the space and time dimensions of the pooled data (Gujarati, 2003). The estimates produced by FE (Columns 3 and 6) are viewed as more appropriate given the fact that we are dealing with panel data (Baltagi, 2005). We thus employ FE in our further analysis. 
We further examine our first hypothesis by controlling for the effect of leasing. The second hypothesis is also tested by controlling for the effect of leverage. The results are reported in Table 5. As reported in Columns 1 through 3, leverage (DRM) is negatively related to CEO equity incentives. Columns 1 and 3 report the negative relationship between finance leases (FLRM) and CEO equity incentives after we have controlled for leverage. Column 2 and 3 report the negative relationship between operating leases (OLRM) and CEO equity incentives after we have controlled for leverage. Taken together, these results are consistent with the substitutability theory we introduced in this study.

\section{Insert Table 5 about here}

The substitutability theory suggests that firms with greater use of debt and/or leases will implement less equity incentives in alleviating agency cost. If firms have a choice between debt and lease financing, the regression results in Column (3) of Table 5 indicate finance lease as a stronger substitute for CEO equity incentives. This is reflected through the coefficient on FLRM (i.e., -8.3424**), which is greater than the coefficients on DRM (i.e., -2.7048**) and OLRM (i.e., -7.1018**).

Nevertheless, we have previously gathered from Figure 1 that finance lease (FLRM) and debt (DRM) are positively correlated. This implies that firms that are strongly debt financed also make use of finance lease and vice versa. We then estimate a model with interaction (i.e., DRM*FLRM) to test the ability of the simultaneous presence of debt and finance lease to substitute equity-based pay. The results reported in Column 4 of 
Table 5 show that the presence of finance lease to complement debt has form a stronger substitutability effect than debt alone.

If firms that are strongly debt financed make use of finance lease too as suggested by the debt-leasing complementary theory, they will gain even greater substitutability effect by taking on operating lease. Consistent with this notion, Column 4 shows that the simultaneous presence of both debt and operating lease serves as the strongest substitute for CEO equity incentives. This is evidenced by the coefficient on DRM*OLRM $\left(-34.4125^{* *}\right)$, which is of greater magnitude than the coefficient on DRM*FLRM (-16.0001**) that does not incorporate operating lease.

Our regression results also report significant relations between several important variables and CEO equity incentives. There is a significant positive relation between growth opportunities (MTB) and CEO equity incentives. As suggested by Yermack (1995), firms with greater growth opportunities tend to have a higher degree of information asymmetry; hence, such firms experience difficulties in monitoring and evaluating the success of managers in choosing among investments. This scenario suggests that a greater use of equity incentives may assist in ensuring the alignment of manager and shareholder interests. Significant positive relations between CEO equity incentives and CEO ownership (CEOWN), as well as tenure (CEOTEN), are expected because these two governance variables can ascertain better alignment of interests with shareholders. 


\section{Conclusions}

This paper introduces a theory that suggests the substitutability of equity incentives and debt/lease financing. This theory is built upon the agency theory that has acknowledged equity- based compensation and fixed claim financing (i.e., debt and leasing) as corporate governance mechanisms to discipline or incentivise managers to use corporate resources more efficiently. The presence of debt/lease commitments will get the managers to avoid wastage and spend corporate resources efficiently so that the financial commitments can be met, otherwise they risk losing their jobs and reputation should the firm goes into liquidation resulting from default repayments. Awarding managers with equity incentives will also discourage managers to use corporate resources for private benefits, and they will instead invest in projects with positive net present values with an expectation to increase the firm's share price hence the value of their equity-based compensation.

Prior studies have acknowledged lease-debt substitutability, and therefore, our study contributes by introducing the substitutability of equity-based compensation and debt/lease financing. To our knowledge, empirical investigation along the substitutability of leases and equity-based compensation is currently non-existent perhaps due to the absence of a database that can provide comprehensive data on both operating leases and equity-based compensation. Although the data on finance leases were available from the balance sheets of the firms, the data on operating leases and equity-based compensation used in this study were hand-collected. This laborious process has resulted in the final sample consists of 700 firm-year observations over a five-year period (i.e., 140 firms for the period from 1999 to 2003). 
Overall, our findings are consistent with the substitutability theory that suggests firms with greater use of debt and/or leases will implement less equity incentives in alleviating managerial self-serving behaviour. This is evidenced by the negative relationship between CEO equity incentives and leverage, and CEO equity incentives and leases. Essentially, our findings represent fresh empirical evidence and renewed interpretation regarding the relationship between executive equity-based incentives and firm's financing choices. This is a useful insight to enrich our understanding of the interactions among alternative corporate governance mechanisms to reduce the agency cost of equity. 


\section{Footnote}

${ }^{1}$ Although Baltagi (2005, p.19) argues that choosing between the fixed effects and random effects estimations "is not as easy a choice as it might seem", a formal Hausman specification test for fixed versus random effects panel estimation is able to identify the estimation method that is suitable for each case in terms of the underlying assumption regarding the error term. The test's null hypothesis is that the difference in coefficients is not systematic (or random). The random effects estimate is preferred if the null hypothesis cannot be rejected. 


\section{References}

Adams, M. and Hardwick, P. 1998. Determinants of the leasing decision in United Kingdom listed companies, Applied Financial Economics, 8: 487-494.

Adam, T. and Goyal, V.K. 2008. The investment opportunity set and its proxy variables, Journal of Financial Research, 31: 41-63.

Adedeji, A. and Stapleton, R.C. 1996. Leases, debt and taxable capacity, Applied Financial Economics, 6: 71-83.

Baltagi, B.H. 2005. Econometric Analysis of Panel Data. 3rd ed. Chichester: John Wiley \& Sons.

Beattie, V., Edwards, K. and Goodacre, A. 1998. The impact of constructive operating lease capitalisation on key accounting ratios, Accounting and Business Research, 28: 233-254.

Beattie, V., Goodacre, A. and Thomson, S. 2000. Operating leases and the assessment of lease-debt substitutability, Journal of Banking and Finance, 24: 427-470.

Bevan, A.A. and Danbolt, J. 2002. Capital structure and its determinants in the UK a decompositional analysis, Applied Financial Economics, 12: 159-170. 
Brick, I.E., Palmon, O. and Wald, J.K. 2006. CEO compensation, director compensation and firm performance: evidence of cronyism?, Journal of Corporate Finance, 12: 403-423.

Conyon, M.J., Core, J.E. and Guay, W.R. 2011. Are US CEOs paid more than UK CEOs? Inferences from risk-adjusted pay, Review of Financial Studies, 24: 402-438.

Core, J.E., Holthausen, R.W. and Larcker, D.F. 1999. Corporate governance, chief executive officer compensation and firm performance, Journal of Financial Economics, 51: 371-406.

de Jong, A., Kabir, R. and Nguyen, T.T. 2008. Capital structure around the world: the roles of firm- and country-specific determinants, Journal of Banking and Finance, 32: 1954-1969.

Ertugrul, M. and Hegde, S. 2008. Board compensation practices and agency costs of debt, Journal of Corporate Finance, 14: 512-531.

\section{Gujarati, D. N. 2003. Basic Econometric, Fourth Ed. New York: McGraw Hill.}

Graham, J.R., Lemmon, M.L. and Schallheim, J.S. 1998. Debt, leases, taxes, and the endogeneity of corporate tax status, Journal of Finance, 53: 131-162.

Hall, B.J. and Liebman, J.B., 1998. Are CEOs really paid like bureaucrats?, Quarterly Journal of Economics, 113: 653-691. 
Jensen, M.C., 1986. Agency costs of free cash flow, corporate finance and takeovers, The American Economic Review, 76: 323-329.

Jensen, M.C. and Meckling, W.H. 1976. Theory of the firm: managerial behaviour, agency costs and ownership structure, Journal of Financial Economics, 3: 305-360.

Jensen, M.C. and Murphy, K.J. 1990. Performance pay and top management incentives. Journal of Political Economy, 98: 225-264.

John, T.A. and John, K. 1993. Top-management compensation and capital structure, Journal of Finance, 48: 949-974.

John, K., Mehran, H. and Qian, Y. 2010. Outside monitoring and CEO compensation in the banking industry, Journal of Corporate Finance, 16: 383-399.

Kuang, F. and Qin, B. 2009. Performance-vested stock options and pay-performance sensitivity, British Accounting Review, 41: 46-61.

Krishnan, V.S. and Moyer, R.C. 1994. Bankruptcy costs and the financial leasing decision, Financial Management, 23: 31-42.

Mehran, H., Taggart, R.A. and Yermack, D. 1999. CEO ownership, leasing and debt financing, Financial Management, 28: 5-14. 
Murphy, K. 1999. Executive compensation. In: O. Ashenfelter and D. Card, eds. Handbook of Labor Economics. Vol. 3. Amsterdam: North-Holland, 2485-2563.

Ortiz-Molina, H. 2007. Executive compensation and capital structure: the effects of convertible debt and straight debt on CEO pay, Journal of Accounting and Economics, 43: 69-93.

Robicheaux, S.H., Fu, X. and Ligon, J.A. 2008. Lease financing and corporate governance. Financial Review, 43: 403-437.

Smith, C.W. and Warner, J. 1979. On financial contracting: an analysis of bond covenants, Journal of Financial Economics, 7: 117-161.

Stulz, R.M. and Johnson, H. 1985. An analysis of secured debt, Journal of Financial Economics, 25: 501-521.

White, H., 1980. A heteroskedasticity-consistent covariance matrix estimator and a direct test for heteroskedascticity, Econometrica, 48: 817-838.

Yermack, D. 1995. Do corporations award CEO stock options effectively?, Journal of Financial Economics, 39: 237-269.

Yermack, D. 2006. Flights of fancy: Corporate jets, CEO perquisites, and inferior shareholder returns, Journal of Financial Economics, 80: 211-242. 
Zhang, Y. 2009. Are Debt and Incentive Compensation Substitutes in Controlling the Free Cash Flow Agency Problem?, Financial Management, 38: 507-541. 


\section{Appendix}

\section{Variable Definitions}

\section{Variable Name}

CEO equity incentives (INCENT)

Book leverage (DRB)

Market leverage (DRM)

Finance lease

Operating lease

Firm characteristics

Size

Stock return

Growth opportunities (MTB)

Adjusted market value (£b)

Adjusted book value (£b)

CEO stockholding (CEOWN)

CEO tenure (CEOTEN)

Executive directors (EXEC)

\section{Definitions}

(Share price) $\times($ the number of shares held $)+($ share price $) \times($ option delta) $\times$ (the number of options held). This incentive measure is a scaled version (i.e., multiplied by 100) of a commonly used incentive measure: a dollar change in a CEO's wealth from a $1 \%$ stock price increase (Conyon, Core and Guay, 2011).

Book value of long-term debt (net of finance leases) divided by the adjusted book value of a firm.

Book value of long-term debt (net of finance leases) divided by the adjusted market value of a firm.

Finance leases divided by the adjusted book value of a firm (FLRB); finance leases divided by the adjusted market value of a firm (FLRM).

Operating leases divided by the adjusted book value of a firm (OLRB); operating leases divided by the adjusted market value of a firm (OLRM).

The natural logarithm of sales.

The natural logarithm of the annual change of a firm's return index.

The ratio of the adjusted market value to the adjusted book value.

The book value of total assets minus the book value of equity plus the market value of equity plus the present value of operating lease assets.

The book value of total assets plus the present value of operating lease assets.

The percentage of a firm's common stock that is owned by its CEO.

The natural logarithm of the number of years that a CEO has held the position of CEO at a firm.

The number of executive directors divided by the number of nonexecutive directors. 
Figure 1

Scatter Diagrams of Leverage (DRM), Finance Lease (FLRM) and Operating Lease (OLRM)

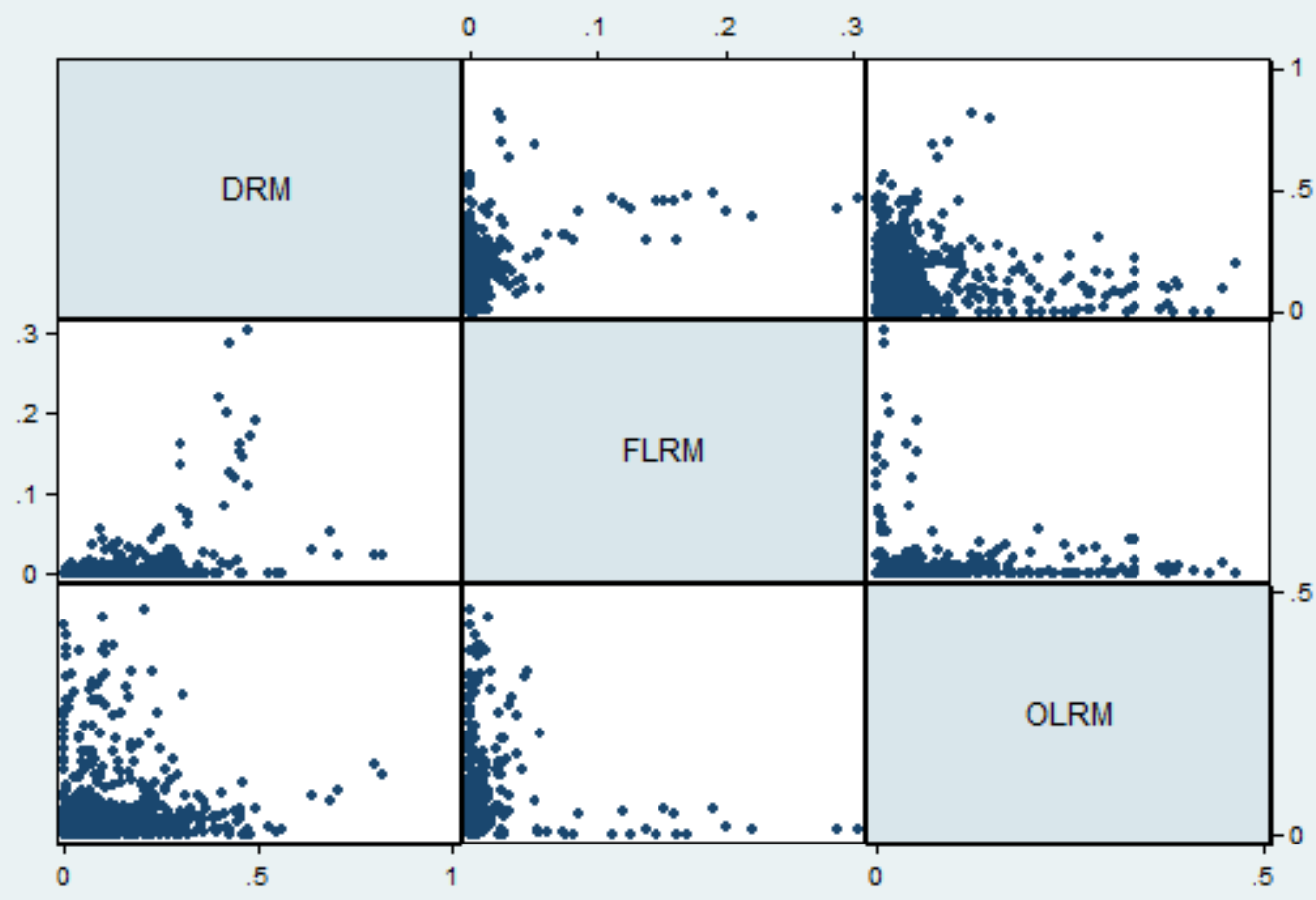


Table 1

\section{Selection of Sample Firms}

\section{Panel A. Sample selection}

Number of non-financial FTSE350 firms

Firms with unavailable data for at least one year for the following reasons:

- takeover/delisted

- annual report not available

- required data in Datastream not available

Total number of sample firms

\section{Panel B. Industry classification}

Industry

Mining

Manufacturing

Construction

Wholesale and Retail

Transportation and Communication

Utilities

Other

Total
Number of firms

Percentage

The sample consists of 140 non-financial UK firms during the 1999-2003 period. Firms are classified into different industries using the UK Primary Standard Industrial Classification Codes from the Financial Analysis Made Easy (FAME) database. 
Table 2

Summary Statistics of Key Variables

\begin{tabular}{|c|c|c|c|c|c|}
\hline Variable & Mean & Median & Std. Dev. & Min. & Max. \\
\hline \multicolumn{6}{|l|}{ Dependent variable } \\
\hline CEO equity incentives (INCENT) (£m) & 9.4986 & 1.2677 & 31.4099 & 0.0000 & 323.3405 \\
\hline \multicolumn{6}{|l|}{ Financing variables } \\
\hline Long-term debt / adjusted book value (DRB) & 0.1884 & 0.1587 & 0.1532 & 0.0000 & 1.1654 \\
\hline Long-term debt / adjusted market value (DRM) & 0.1330 & 0.1040 & 0.1227 & 0.0000 & 0.8188 \\
\hline Long-term finance lease liability / adjusted book value (FLRB) & 0.0082 & 0.0004 & 0.0267 & 0.0000 & 0.2918 \\
\hline Long-term finance lease liability / adjusted market value (FLRM) & 0.0072 & 0.0025 & 0.0274 & 0.0000 & 0.3039 \\
\hline Long-term operating lease liability / adjusted book value (OLRB) & 0.0810 & 0.0403 & 0.1129 & 0.0000 & 0.7821 \\
\hline Long-term operating lease liability / adjusted market value (OLRM) & 0.0522 & 0.0236 & 0.0780 & 0.0000 & 0.4638 \\
\hline Long-term debt $(£ b)$ & 0.8848 & 0.2478 & 1.8897 & 0.0000 & 18.7750 \\
\hline Long-term finance lease liability (£b) & 0.0466 & 0.0001 & 0.2107 & 0.0000 & 2.4300 \\
\hline Long-term operating lease liability $(£ b)$ & 0.2363 & 0.0610 & 0.4345 & 0.0000 & 3.4315 \\
\hline Adjusted book value (£b) & 5.2139 & 1.4848 & 15.3297 & 0.0427 & 172.6844 \\
\hline Adjusted market value (£b) & 7.8846 & 2.3508 & 20.1047 & 0.1330 & 227.3096 \\
\hline \multicolumn{6}{|l|}{ Firm characteristic variables } \\
\hline Sales $(£ b)$ & 3.6276 & 1.3274 & 10.1214 & 0.0177 & 141.3427 \\
\hline Growth opportunities (MTB) & 2.0629 & 1.4281 & 3.7571 & 0.5402 & 83.5721 \\
\hline \multicolumn{6}{|l|}{ Control variables } \\
\hline CEO stockholding (CEOWN) & 0.0111 & 0.0003 & 0.0441 & 0.0000 & 0.3624 \\
\hline Executive directors (EXEC) & 0.9950 & 0.8819 & 0.5633 & 0.1000 & 4.0000 \\
\hline CEO tenure (years) (CEOTEN) & 5.8664 & 4.0000 & 5.3477 & 0.5000 & 33.0000 \\
\hline
\end{tabular}

The sample consists of 140 FTSE350 firms during the 1999-2003 period (700 firm-year observations). All variables are defined in the appendix. 
Table 3

Debt and CEO Equity Incentives

\begin{tabular}{|c|c|c|c|c|c|}
\hline & (1) & (2) & (3) & (4) & (5) \\
\hline Independent variable & Tobit & $O L S$ & & & \\
\hline \multirow[t]{2}{*}{$D R B$} & $-0.7128^{*}$ & $-0.6915^{*}$ & & & \\
\hline & $(-1.70)$ & $(-1.70)$ & & & \\
\hline \multirow[t]{2}{*}{$D R M$} & & & $-2.8481 * * *$ & $-2.8253 * * *$ & $-2.9749 * * *$ \\
\hline & & & $(-5.33)$ & $(-5.36)$ & $(-2.66)$ \\
\hline \multirow[t]{2}{*}{ SIZE } & $0.3146^{* * *}$ & $0.3151 * * *$ & $0.3091 * * *$ & $0.3096^{* * *}$ & 0.3062 \\
\hline & $(6.68)$ & $(6.81)$ & $(6.68)$ & $(6.88)$ & (1.24) \\
\hline \multirow[t]{2}{*}{ MTB } & $0.0778 * * *$ & $0.0779 * *$ & $0.0667 * * *$ & $0.0669 * * *$ & $0.0573 * *$ \\
\hline & $(4.56)$ & $(2.33)$ & $(3.95)$ & $(2.47)$ & $(2.26)$ \\
\hline \multirow[t]{2}{*}{ CEOWN } & $19.6657 * * *$ & $19.6416^{* * *}$ & $19.0249 * * *$ & $19.0049 * * *$ & $28.3652 * * *$ \\
\hline & $(12.46)$ & $(9.87)$ & (12.23) & $(9.65)$ & $(3.85)$ \\
\hline \multirow[t]{2}{*}{ CEOTEN } & $0.4331 * * *$ & $0.4310 * * *$ & $0.4330 * * *$ & $0.4309 * * *$ & $0.2430 * * *$ \\
\hline & $(6.82)$ & $(6.54)$ & $(6.95)$ & $(6.65)$ & $(2.87)$ \\
\hline \multirow[t]{2}{*}{$E X E C$} & $-0.2440 * *$ & $-0.2433^{*}$ & $-0.2861 * *$ & $-0.2856^{* *}$ & 0.1088 \\
\hline & $(-1.95)$ & $(-1.71)$ & $(-2.33)$ & $(-2.01)$ & $(0.56)$ \\
\hline \multirow[t]{2}{*}{ CONSTANT } & 0.8847 & 0.8806 & $1.4969 * *$ & $1.4938^{*}$ & 1.9937 \\
\hline & (1.19) & (1.14) & (2.04) & (1.96) & $(0.57)$ \\
\hline Pseudo $R^{2}$ & 0.1128 & & 0.1213 & & \\
\hline Adjusted $R^{2}$ & & 0.3725 & & 0.3951 & \\
\hline$R^{2}$ overall & & & & & 0.3179 \\
\hline & 17.72 \\
\hline \multicolumn{6}{|c|}{$\begin{array}{l}\text { The sample consists of } 140 \text { FTSE350 firms during the } 1999-2003 \text { period ( } 700 \text { firm-year observations). The } \\
\text { dependent variable is CEO equity incentives. Both year and industry dummies are included in the Tobit and } \\
\text { OLS estimates, whereas only a year dummy is included in the fixed effects estimates. The coefficients for year } \\
\text { and industry dummies are not reported for reasons of brevity. All variables are defined in the appendix. White's } \\
\text { heteroscedastic-consistent covariance matrix estimation (1980) is used to correct for heteroscedasticity in the } \\
\text { OLS estimates. } t \text {-statistics are reported in parentheses for the Tobit, OLS and fixed effects estimates. Pseudo } \\
R^{2} \text { values are reported in the Tobit estimates, whereas adjusted } R^{2} \text { values are reported in the OLS estimates. } \\
\text { For the panel data regressions, fixed effects estimates are preferred over random effects estimates based on the } \\
\text { Hausman test. } * * * * * \text { and } * \text { indicate statistical significance at the } 1 \%, 5 \% \text { and } 10 \% \text { levels, respectively (two- } \\
\text { tailed test). }\end{array}$} \\
\hline
\end{tabular}




\section{Table 4}

Finance Leases, Operating Leases and CEO Equity Incentives

\begin{tabular}{|c|c|c|c|c|c|c|}
\hline $\begin{array}{l}\text { Independent } \\
\text { variable }\end{array}$ & $\begin{array}{c}\text { (1) } \\
\text { Tobit }\end{array}$ & $\begin{array}{l}(2) \\
O L S\end{array}$ & $\begin{array}{l}\text { (3) } \\
F E\end{array}$ & $\begin{array}{l}\text { (4) } \\
\text { Tobit }\end{array}$ & $\begin{array}{l}(5) \\
O L S\end{array}$ & $\begin{array}{l}\text { (6) } \\
F E\end{array}$ \\
\hline FLRM & $\begin{array}{c}-17.2745^{* * *} \\
(-6.86)\end{array}$ & $\begin{array}{c}-16.9312 * * * \\
(-10.52)\end{array}$ & $\begin{array}{c}-10.7323 * * * \\
(-3.00)\end{array}$ & & & \\
\hline OLRM & & & & $\begin{array}{c}-0.4466 \\
(-0.48)\end{array}$ & $\begin{array}{c}-0.4086 \\
(-0.43)\end{array}$ & $\begin{array}{c}-7.5342 * * \\
(-2.15)\end{array}$ \\
\hline SIZE & $\begin{array}{c}0.3103^{* * *} \\
(6.79)\end{array}$ & $\begin{array}{c}0.3105^{* * *} \\
(6.83)\end{array}$ & $\begin{array}{l}0.1905 \\
(0.73)\end{array}$ & $\begin{array}{c}0.3148 * * * \\
(6.67)\end{array}$ & $\begin{array}{c}0.3153^{* * *} \\
(6.80)\end{array}$ & $\begin{array}{l}0.1727 \\
(0.67)\end{array}$ \\
\hline MTB & $\begin{array}{c}0.0756^{* * * *} \\
(4.59)\end{array}$ & $\begin{array}{c}0.0758 * * \\
(2.43)\end{array}$ & $\begin{array}{c}0.0584 * * \\
(2.18)\end{array}$ & $\begin{array}{c}0.0795 * * * \\
(4.65)\end{array}$ & $\begin{array}{c}0.0797 * * \\
(2.37)\end{array}$ & $\begin{array}{c}0.0526 * * \\
(2.14)\end{array}$ \\
\hline CEOWN & $\begin{array}{c}19.7670 * * * \\
(12.92)\end{array}$ & $\begin{array}{c}19.7401 * * * \\
(10.14)\end{array}$ & $\begin{array}{c}28.5936^{* * *} \\
(3.90)\end{array}$ & $\begin{array}{c}19.8674 * * * \\
(12.45)\end{array}$ & $\begin{array}{c}19.8312 * * * \\
(9.64)\end{array}$ & $\begin{array}{c}27.1860^{* * * *} \\
(4.18)\end{array}$ \\
\hline CEOTEN & $\begin{array}{c}0.4419 * * * \\
(7.18)\end{array}$ & $\begin{array}{c}0.4400 * * * \\
(6.73)\end{array}$ & $\begin{array}{c}0.2453^{* * * *} \\
(2.87)\end{array}$ & $\begin{array}{c}0.4389 * * * \\
(6.87)\end{array}$ & $\begin{array}{c}0.4365^{* * *} \\
(6.45)\end{array}$ & $\begin{array}{c}0.2448 * * * \\
(2.87)\end{array}$ \\
\hline EXEC & $\begin{array}{c}-0.2461 * * \\
(-2.04)\end{array}$ & $\begin{array}{c}-0.2458 * \\
(-1.72)\end{array}$ & $\begin{array}{l}0.1036 \\
(0.54)\end{array}$ & $\begin{array}{c}-0.2205 * \\
(1.77)\end{array}$ & $\begin{array}{c}-0.2203 \\
(1.30)\end{array}$ & $\begin{array}{l}0.0620 \\
(0.32)\end{array}$ \\
\hline CONSTANT & $\begin{array}{c}1.7834 * * \\
(2.46)\end{array}$ & $\begin{array}{c}1.7767 * * \\
(2.5)\end{array}$ & $\begin{array}{l}3.3524 \\
(0.92)\end{array}$ & $\begin{array}{l}0.6471 \\
(0.89)\end{array}$ & $\begin{array}{l}0.6493 \\
(0.83)\end{array}$ & $\begin{array}{l}3.9457 \\
(1.07)\end{array}$ \\
\hline Pseudo $R^{2}$ & 0.1273 & & & 0.1119 & & \\
\hline Adjusted $R^{2}$ & & 0.4100 & 0.4193 & & 0.3702 & \\
\hline $\begin{array}{l}R^{2} \text { overall } \\
\text { Hausman test FE } \\
\text { vs. } R E\left(\chi^{2}\right)\end{array}$ & & & $\begin{array}{r}0.3176 \\
19.08 \\
\end{array}$ & & & $\begin{array}{r}0.2146 \\
19.08 \\
\end{array}$ \\
\hline $\begin{array}{l}\text { The sample consist } \\
\text { is CEO equity ince } \\
\text { dummy is included } \\
\text { of brevity. All vari } \\
\text { is used to correct f } \\
\text { fixed effects estima } \\
\text { OLS estimates. For } \\
\text { Hausman test. ***, }\end{array}$ & $\begin{array}{l}\text { FTSE350 firr } \\
\text { Both year and } \\
\text { ixed effects e: } \\
\text { e defined in t } \\
\text { oscedasticity } \\
\text { eudo } R^{2} \text { value } \\
\text { el data regres } \\
\text { * indicate sta }\end{array}$ & $\begin{array}{l}\text { ing the } 1999- \\
\text { try dummies } \\
\text { es. The coeffi } \\
\text { gendix. White } \\
\text { OLS estimat } \\
\text { reported in th } \\
\text { fixed effects } \\
1 \text { significance }\end{array}$ & $\begin{array}{l}003 \text { period }(70 \\
\text { e included in } \mathrm{t} \\
\text { ents for year a } \\
\text { heteroscedasti } \\
t \text {-statistics ar } \\
\text { Tobit estimate } \\
\text { timates are pre } \\
\text { the } 1 \%, 5 \% \text { a }\end{array}$ & $\begin{array}{l}\text { Tob-year obs } \\
\text { Tobit and C } \\
\text { industry du } \\
\text { onsistent cc } \\
\text { ported in } p \\
\text { vhereas adj } \\
\text { ed over ran } \\
10 \% \text { levels, }\end{array}$ & $\begin{array}{l}\text { ions). The } \\
\text { stimates, w } \\
\text { es are not re } \\
\text { ance matrix } \\
\text { heses for th } \\
R^{2} \text { values } \\
\text { effects estil } \\
\text { ectively (th }\end{array}$ & $\begin{array}{l}\text { ndent variable } \\
\text { as only a year } \\
\text { ted for reasons } \\
\text { mation (1980) } \\
\text { obit, OLS and } \\
\text { reported in the } \\
\text { s based on the } \\
\text { iled test). }\end{array}$ \\
\hline
\end{tabular}


Table 5

Debt, Leases and CEO Equity Incentives

\begin{tabular}{|c|c|c|c|c|}
\hline & (1) & (2) & (3) & (4) \\
\hline Independent variable & $F E$ & $F E$ & $F E$ & $F E$ \\
\hline \multirow[t]{2}{*}{$D R M$} & $-2.8435^{* *}$ & $-2.8242 * *$ & $-2.7048 * *$ & -0.7997 \\
\hline & $(-2.52)$ & $(-2.60)$ & $(-2.46)$ & $(-0.66)$ \\
\hline \multirow[t]{2}{*}{ FLRM } & $-9.0226 * *$ & & $-8.3424 * *$ & \\
\hline & $(-2.39)$ & & $(-2.22)$ & \\
\hline \multirow[t]{2}{*}{ OLRM } & & $-7.2081 * *$ & $-7.1018 * *$ & \\
\hline & & $(-2.19)$ & $(-2.13)$ & \\
\hline \multirow[t]{2}{*}{$D R M * F L R M$} & & & & $-16.0001 * *$ \\
\hline & & & & $(-2.17)$ \\
\hline \multirow[t]{2}{*}{$D R M * O L R M$} & & & & $-34.4125 * *$ \\
\hline & & & & $(-2.20)$ \\
\hline \multirow[t]{2}{*}{ SIZE } & 0.2913 & 0.2722 & 0.2589 & 0.2029 \\
\hline & $(1.20)$ & $(1.12)$ & $(1.08)$ & $(0.83)$ \\
\hline \multirow[t]{2}{*}{$M T B$} & $0.0572 * *$ & $0.0517 * *$ & $0.0516^{* *}$ & $0.0564 * *$ \\
\hline & $(2.25)$ & $(2.20)$ & $(2.19)$ & $(2.22)$ \\
\hline \multirow[t]{2}{*}{ CEOWN } & $28.3111 * * *$ & $26.9572 * * *$ & $26.9280 * * *$ & $26.7132 * * *$ \\
\hline & $(3.84)$ & $(4.10)$ & $(4.10)$ & $(4.23)$ \\
\hline \multirow[t]{2}{*}{ CEOTEN } & $0.2426 * * *$ & $0.2420 * * *$ & $0.2416^{* * *}$ & $0.2528 * * *$ \\
\hline & $(2.86)$ & $(2.86)$ & $(2.85)$ & $(3.01)$ \\
\hline \multirow[t]{2}{*}{ EXEC } & 0.1037 & 0.0633 & 0.0593 & 0.0867 \\
\hline & $(0.53)$ & $(0.33)$ & $(0.31)$ & $(0.45)$ \\
\hline \multirow[t]{2}{*}{ CONSTANT } & 2.2554 & 2.8596 & 3.0888 & 3.4148 \\
\hline & $(0.66)$ & $(0.83)$ & $(0.91)$ & $(0.99)$ \\
\hline \multicolumn{5}{|l|}{ Pseudo $R^{2}$} \\
\hline \multicolumn{5}{|l|}{ Adjusted $R^{2}$} \\
\hline$R^{2}$ overall & 0.3413 & 0.2630 & 0.2286 & 0.3032 \\
\hline Hausman test FE vs. $R E\left(\chi^{2}\right)$ & 18.32 & 27.71 & 28.72 & 32.78 \\
\hline \multicolumn{5}{|c|}{$\begin{array}{l}\text { The sample consists of } 140 \text { FTSE350 firms during the } 1999-2003 \text { period ( } 700 \text { firm-year observations). The } \\
\text { dependent variable is CEO equity incentives. All variables are defined in the appendix. } t \text {-statistics are reported } \\
\text { in parentheses. The coefficients for year dummies are not reported for reasons of brevity. Fixed effects estimates } \\
\text { are preferred over random effects estimates based on the Hausman test. } * * * * * \text { and } * \text { indicate statistical } \\
\text { significance at the } 1 \%, 5 \% \text { and } 10 \% \text { levels, respectively (two-tailed test). }\end{array}$} \\
\hline
\end{tabular}

